\title{
Electrochemical Degradation of Congo Red from Aqueous Solution: Role of Graphite Anode as Electrode Material
}

\author{
Rajvir Kaur and Harpreet Kaur* \\ Department of Chemistry, Punjabi University, Patiala- 147002, Punjab, India
}

Received 01 December 2015; accepted 18 March 2016

\begin{abstract}
The present work has been carried out to study the mechanism of electrochemical degradation of Congo red dye. Electrolysis has been carried out in a single-chamber electrochemical cell having graphite anode and platinum cathode in the presence of $\mathrm{KCl}$ as supporting electrolyte under amperostatic conditions. The potential across the electrodes has been adjusted so that a constant $30 \mathrm{~mA}$ current passed through the cell. The effect of various operating parameters such as current density, initial dye concentration, nature of supporting electrolyte $\mathrm{KCl}, \mathrm{pH}$ and electrode materials, on electrochemical degradation of Congo red dye has been investigated. The decolourization efficiency was assessed through UV-Visible studies which are supported by a percentage reduction in Chemical Oxygen Demand (COD). Kinetic studies indicate that decolourization takes place through a second order diffusion controlled reaction. Energy consumption has been calculated. It is observed from Fourier transform infrared spectroscopy (FTIR) and mass spectra that Congo red dye has been degraded to small molecules. Results indicate that electrochemical degradation of Congo red by using low-cost graphite electrodes proves to be an efficient method at an optimum current density of $1.805 \mathrm{~mA} \mathrm{~cm}^{-2}$.
\end{abstract}

Keywords: COD, Congo red, Electrochemical oxidation, Energy consumption, Graphite anode electrode.

\section{Introduction}

Water pollution refers to the presence of a harmful and objectionable material in water, even at very low concentrations, which makes it unfit for drinking [1]. Water contamination weakens or destroys natural ecosystems that support human health, food production and biodiversity. The problem is especially faced by developing countries, due to rapid increase in industries.

Effluents, especially from textile industries and from other industries like paper, paint, plastic, cosmetics, leather and foodstuffs, etc., contain dyes, which are responsible for various environmental and biological problems [2-5]. Most of the

\footnotetext{
* Corresponding author. E-mail address: preetjudge@yahoo.co.in
} 
azo dyes are not oxidized by conventional physical and biological treatments, because of their complex molecular structures and large sizes [6-7]. Congo red [1-napthalenesulfonic acid, 3,3'-(4,4'-biphenylene bis(azo))bis (4-amino-) disodium salt] is a benzidine-based anionic diazo dye, known to metabolize to benzidine, a carcinogen [8-9]. Congo red mainly occurs in effluents discharged from wood pulp, paper, cotton textile and leather industries, during dyeing operation; about $20 \%$ of it is left in the wastewater. It causes skin irritation and allergic dermatitis in human beings. The presence of dye in water causes tremendous chemico-azo stress on aquatic organisms, including fishes, and sometimes results in their mass mortality. A number of techniques such as electrochemical coagulation [10-11], photocatalytic decolourization [12], electrochemical oxidation [13], adsorption [8,14] and microbiological decomposition [15] have been proposed from time to time for the removal of different types of dyes from effluents. The removal of dyes from wastewater in an economic fashion remains a major problem.

The electrochemical technique has found wide acceptance for wastewater remediation, because it currently offers promising approaches for the prevention of pollution, versatility, environmental compatibility and cost effectiveness [16]. The main reagent is electron, which is a 'clean reagent', this being the most important advantage of that technology, related to environment compatibility [17]. Electrochemical oxidation provides a direct and economically cheap route for the efficient removal of dye from aqueous solution, as a process-integrated environmental protection and maximum energy management method. The electric current induces cell reactions upon the electrodes surface, resulting in the transformation and destruction of the organic compound, and oxidation to $\mathrm{CO}_{2}$ and $\mathrm{H}_{2} \mathrm{O}$ [18]. In indirect electro-oxidation, sodium or potassium chloride are added to wastewater for better conductivity, which results in the formation of hypochlorite ions, by the following mechanism [19]:

$$
\begin{aligned}
& \text { Anode: } 2 \mathrm{Cl}^{-} \rightarrow \mathrm{Cl}_{2}+2 e^{-} \\
& \text {Cathode: } 2 \mathrm{H}_{2} \mathrm{O}+2 e^{-} \rightarrow \mathrm{H}_{2}+2 \mathrm{OH}^{-}
\end{aligned}
$$

In the solution $\mathrm{Cl}_{2}$ hydrolysis occurs according to the following reaction:

$$
\begin{aligned}
& \mathrm{Cl}_{2}+\mathrm{H}_{2} \mathrm{O} \leftrightarrow \mathrm{HOCl}+\mathrm{H}^{+}+\mathrm{Cl}^{-} \\
& \mathrm{HOCl} \leftrightarrow \mathrm{H}^{+}+\mathrm{OCl}^{-}
\end{aligned}
$$

At anode, $\mathrm{O}_{2}$ evolution competes with $\mathrm{Cl}_{2}$ evolution, according to the following reaction:

$$
\mathrm{H}_{2} \mathrm{O} \rightarrow 2 \mathrm{H}^{+}+\frac{1}{2} \mathrm{O}_{2}+2 e^{-}
$$

The overall reaction can be written as:

$$
\text { Dye }+\mathrm{OCl}^{-} \rightarrow \text { intermediates } \rightarrow \mathrm{CO}_{2}+\mathrm{H}_{2} \mathrm{O}+\mathrm{Cl}^{-}
$$


The aim of the present work is thus to study electrochemical oxidation of an aqueous solution of hazardous diazo dye, "Congo red", at graphite anode and Pt cathode. The influence of current density and anode material on the COD and dye removal has been investigated, in order to identify optimal conditions, which gives high current efficiency and has very low energy requirements.

\section{Experimental}

\section{Materials}

Congo red (commercial name), an anionic diazo dye (CAS No. 573-58-0, M.W. 696.68 $\mathrm{gmol}^{-1}$ ), has been obtained from sd fine-chem limited, Mumbai. All the chemicals were used as procured. Water has been purified by adding potassium permanganate and a pellet of potassium hydroxide, and then it has been fractionally distilled. Double distilled water has been used to prepare the desired concentration of dye solutions and of reagents.

\section{Instrumentation}

The electrochemical experiments have been carried out using a digital DC Electrophoresis power supply, as shown in Fig. 1. The electrochemical cell consists of an undivided cell with two monopolar electrodes, i.e., graphite has been used as anode, and platinum as a cathode. Graphite electrodes have a total effective electrode area of $16.623 \mathrm{~cm}^{2}$. The electrodes have been placed vertical and parallel to each other, and connected to a digital DC power supply (0 - 100 $\mathrm{mA}, 1-300 \mathrm{~V}$ ) equipped with amperostatic operational conditions. The potential across the electrodes has been adjusted, so that a current of $30 \mathrm{~mA}$ has passed through the cell. Potassium chloride has been used as supporting electrolyte. The optimum condition during electrolysis has been selected as follows: current density at $1.805 \mathrm{~mA} \mathrm{~cm}^{-2}$; initial dye concentration of $100 \mathrm{mgL}^{-1}$; amount of $\mathrm{KCl}$ $5 \mathrm{gL}^{-1}$ at original solution $\mathrm{pH}$ and room temperature. The electrolytic solution has been stirred thoroughly with the help of a magnetic stirrer during electrolysis.

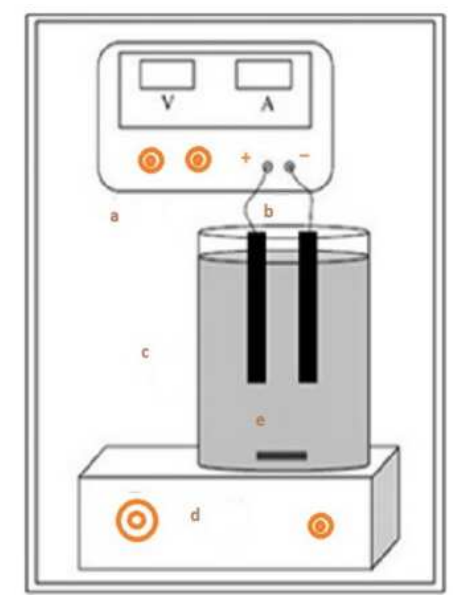

Figure 1. Schematic diagram of the experimental setup. (a. DC power supply; b. Electrode pair (Anode - Graphite and Cathode - Pt); c. Electrolytic cell; d. Magnetic stirrer; e. Magnetic bead). 


\section{Electrochemical degradation studies}

The electrolysis of a $100 \mathrm{~mL}$ solution of dye containing $5 \mathrm{gL}^{-1}$ of supporting electrolyte $\mathrm{KCl}$ has been carried out at graphite anode and platinum cathode. 2 $\mathrm{mL}$ of solution have been withdrawn at pre-set intervals of time, and the amount of dye decomposed was measured with the help of a Shimadzu-1800 UV-Visible Spectrophotometer at $484.95 \mathrm{~nm}$. In order to study the effect of different parameters, electrolysis has been carried out by varying the current density, initial dye concentration, electrolysis time, amount of supporting electrolytes, $\mathrm{pH}$, cathode and electrode materials. All the reagents were prepared and analysed as per standard methods. All the experiments were performed at room temperature. The percentage of dye removed was calculated using the following relation:

$$
\text { \% Dye removal }=\frac{c_{0}-c_{t}}{c_{o}} \times 100
$$

where $\mathrm{C}_{\mathrm{o}}$ and $\mathrm{C}_{\mathrm{t}}$ are the initial dye concentration, and the dye concentration at time $\mathrm{t}$ in solution $\left(\mathrm{mgL}^{-1}\right)$, respectively.

Electrochemical oxidation degrades the organic pollutants in wastewater, and thereby causes the reduction in COD and decrease in colour. The chemical oxygen demand (COD) was measured by volumetric analytical method, as reported in literature [20].

\section{Results and discussion}

\section{Optimization of current density}

Fig. 2 shows that different current densities (0.602, 1.203, 1.805 and $2.406 \mathrm{~mA}$ $\mathrm{cm}^{-2}$ ) with contact time play an important role in the study of electrochemical degradation of Congo red dye in an aqueous solution. As the current density increases, the rate of hypochlorite produced increases at constant $\mathrm{pH}$ [21]. Also, the amount of $\mathrm{H}_{2}$ gas evolved on cathode increases with increasing applied current density, as per Faraday's law.

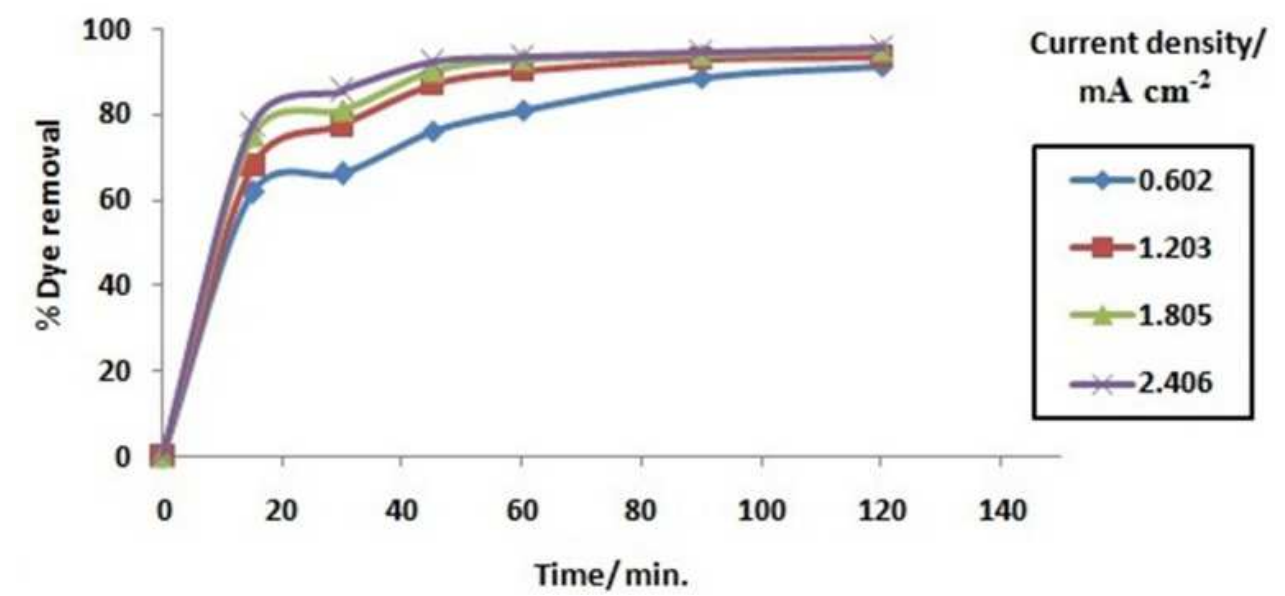

Figure 2. Effect of current density with time on percentage dye removal. $\left(\mathrm{C}_{0}=100 \mathrm{mg}\right.$ $\mathrm{L}^{-1}, \mathrm{KCl}=5 \mathrm{gL}^{-1}, \mathrm{pH}=7.86$, Temperature $=20 \pm 2{ }^{\circ} \mathrm{C}$ ). 


\section{Optimization of initial dye concentration}

The effect of the initial dye concentration on the removal efficiency of colour with contact time, at broad range of dye concentration, is shown in Fig. 3. The rate of dye decolourization decreased with increasing initial dye concentration at constant current. During electrolysis, by increasing the dye concentration, the molecules of dye tend to associate to large molecules of low diffusivity, which lowers the rate of dye diffusion to the anode, with a consequent decrease in the dye removal [22].

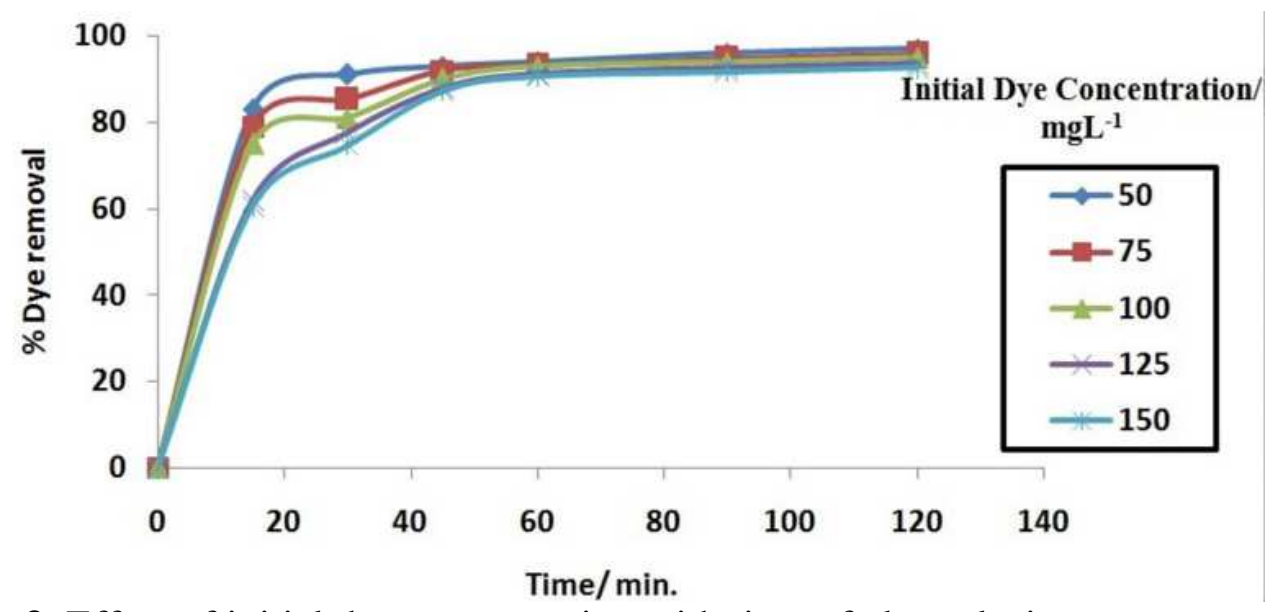

Figure 3. Effect of initial dye concentration with time of electrolysis on percentage dye removal. (Current density $=1.805 \mathrm{~mA} \mathrm{~cm}^{-2}, \mathrm{KCl}=5 \mathrm{gL}^{-1}, \mathrm{pH}=7.86, \mathrm{~T}=20 \pm 2{ }^{\circ} \mathrm{C}$ ).

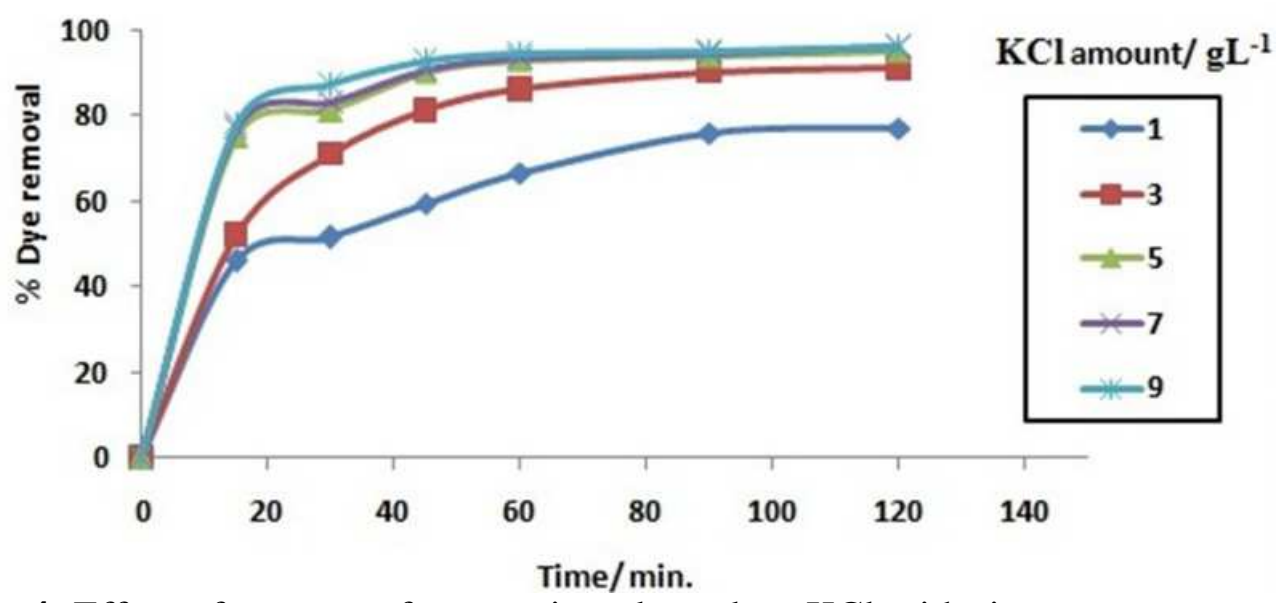

Figure 4. Effect of amount of supporting electrolyte $\mathrm{KCl}$ with time on percentage dye removal. (Current density $=1.805 \mathrm{~mA} \mathrm{~cm}^{-2}, \mathrm{C}_{\mathrm{o}}=100 \mathrm{mgL}^{-1}, \mathrm{pH}=7.86$, Temperature $=$ $\left.20 \pm 2{ }^{\circ} \mathrm{C}\right)$.

\section{Optimization of supporting electrolytes}

It is evident from Fig. 4 that the rate of colour removal increases with the increase in the amount of supporting electrolytes. This may be due to the fact that, with an increase in concentration of supporting electrolytes, more hypochlorite ions are formed, which increases the dye oxidation. But, at a very high concentration, the percentage removal of dye becomes nearly constant, which may be due to the evolution of oxygen at high concentration levels [23]. 
A comparative study of $\mathrm{KCl}$ with $\mathrm{NaCl}$ as supporting electrolytes has been carried out at optimum conditions. Fig. 5 depicts that $\mathrm{KCl}$ is a more efficient supporting electrolyte, as compared with $\mathrm{NaCl}$, at initial stages.

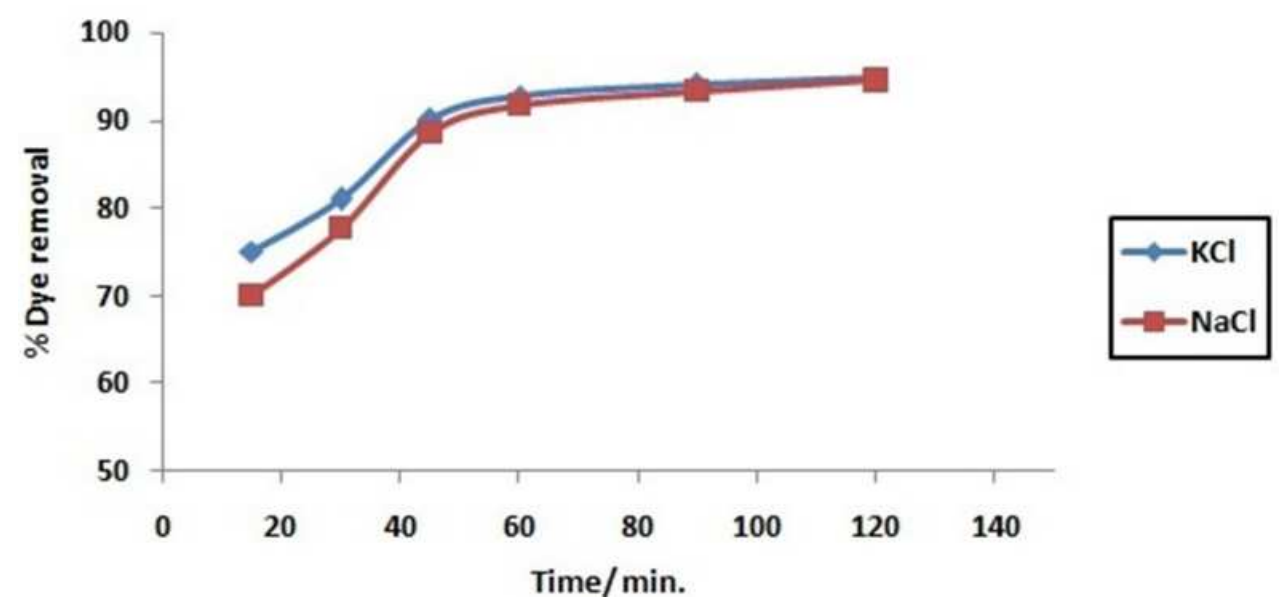

Figure 5. Comparison of amount of supporting electrolyte $\mathrm{KCl}$ with $\mathrm{NaCl}$ with time of electrolysis on percentage dye removal. (Current density $=1.805 \mathrm{~mA} \mathrm{~cm}^{-2}, \mathrm{C}_{\mathrm{o}}=100 \mathrm{mg}$ $\mathrm{L}^{-1}, \mathrm{pH}=7.86, \mathrm{~T}=20 \pm 2{ }^{\circ} \mathrm{C}$ ).

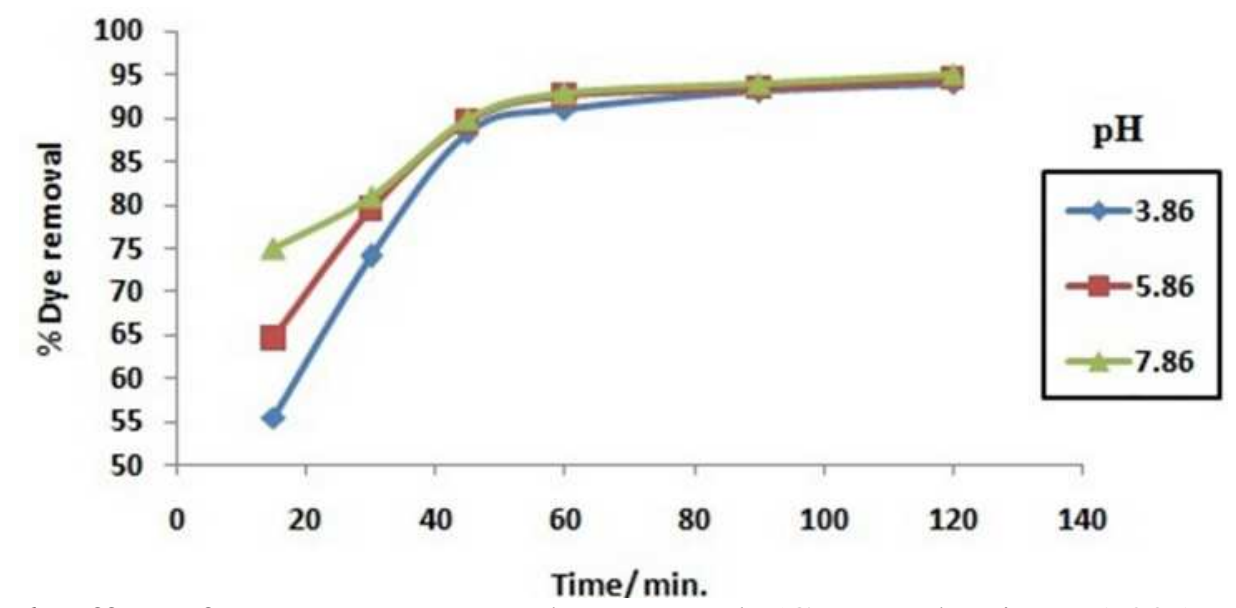

Figure 6. Effect of $\mathrm{pH}$ on percentage dye removal. (Current density $=1.805 \mathrm{~mA} \mathrm{~cm}^{-2}$, $\left.\mathrm{C}_{\mathrm{o}}=100 \mathrm{mgL}^{-1}, \mathrm{KCl}=5 \mathrm{gL}^{-1}, \mathrm{~T}=20 \pm 2{ }^{\circ} \mathrm{C}\right)$.

\section{Optimization of pH}

In order to study the effect of $\mathrm{pH}$ on the degradation of Congo red, the $\mathrm{pH}$ of the solution was varied from 3.86 to 7.86 , at optimum conditions at room temperature. It is shown from Fig. 6 that the solution's pH affects the rate of dye degradation only at initial stages.

\section{Effect of cathode and anode material}

In order to evaluate the efficiency of electrode materials towards electrochemical oxidation of Congo red dye, the electrolysis has been carried out by varying electrode materials (Fig. 7). It has been observed that when Pt has been used as electrodes then there is a $99.5 \%$ degradation of the dye, but when cathode material is replaced with graphite, then there is a slight decrease in dye degradation at final stage. In its turn, when the anode is replaced with graphite, 
then there is a decrease in percentage of dye degradation both at initial and final stage. From this, it can be concluded that although the efficiency of dye degradation at the graphite electrode is low at middle stage, it grows to $90 \%$. Therefore, it can be used as an alternative electrode material for dye pollution monitoring, instead of the costly platinum electrode.

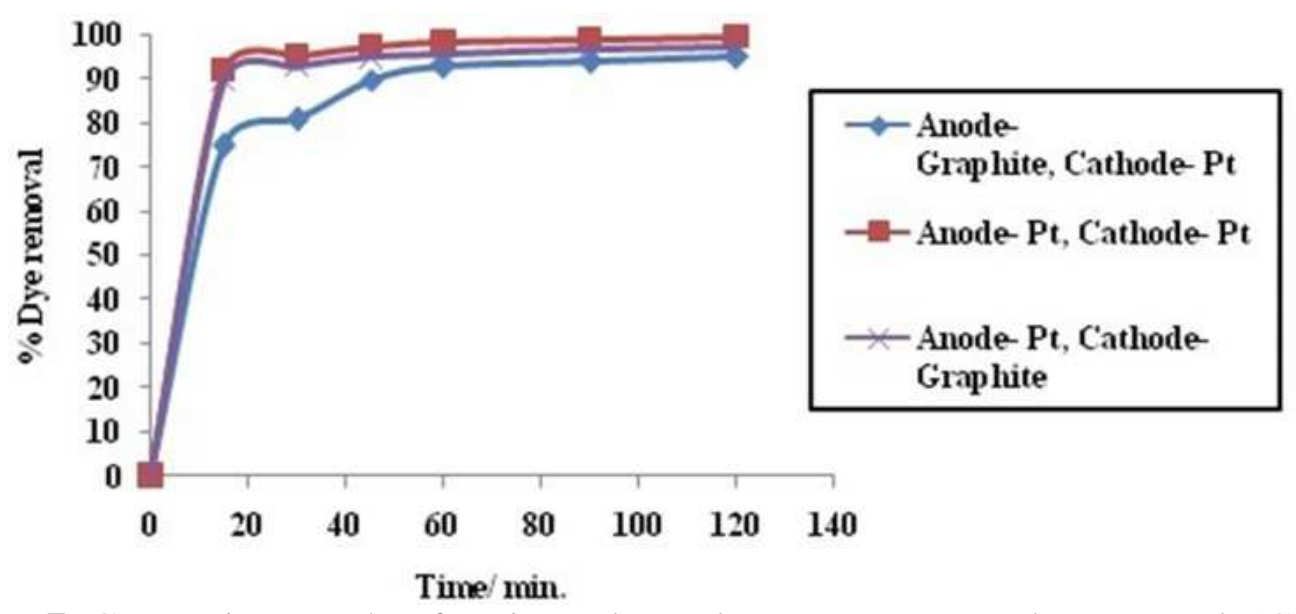

Figure 7. Comparison study of various electrodes on percentage dye removal. (Current density $=1.805 \mathrm{~mA} \mathrm{~cm}^{-2}, \mathrm{C}_{\mathrm{o}}=100 \mathrm{mgL}^{-1}, \mathrm{KCl}=5 \mathrm{gL}^{-1}$, Temperature $=20 \pm 2{ }^{\circ} \mathrm{C}$ ).

\section{Kinetic studies}

Many kinetic models have been applied to study the controlling mechanism of dye removal from aqueous solution. In order to investigate the mechanism of electrolysis of Congo red dye, the following kinetic models have been considered.

\section{Kinetic first-order rate equation}

In an attempt to correlate the present data with a kinetic first-order rate equation, a graph is plotted between $\ln \left(\mathrm{C}_{\mathrm{o}} / \mathrm{C}_{\mathrm{e}}\right)$ versus time $\mathrm{t}$. The results show that the data do not follow first-order equation.

Kinetic second-order rate equation

The data are then subjected to kinetics of second-order equation. The rate at which is expressed is:

$$
\frac{c_{0}-c_{t}}{c_{t} c_{o}}=K_{2} t
$$

where $\mathrm{C}_{\mathrm{o}}$ and $\mathrm{C}_{\mathrm{t}}$ are the initial dye concentration and concentration of dye at time $\mathrm{t}$ in solution $\left(\mathrm{mgL}^{-1}\right)$, respectively; and $\mathrm{K}_{2}$ is the second-order rate constant $\left(\min ^{-1}\right)$.

It is evident from Fig. 8 that the data fitted well with a kinetic second-order rate equation. Rate constant value is listed in Table 1, which shows decrease in the rate constant value $\mathrm{K}_{2}$, with different initial dye concentration levels for the electrolytic removal of dye. 


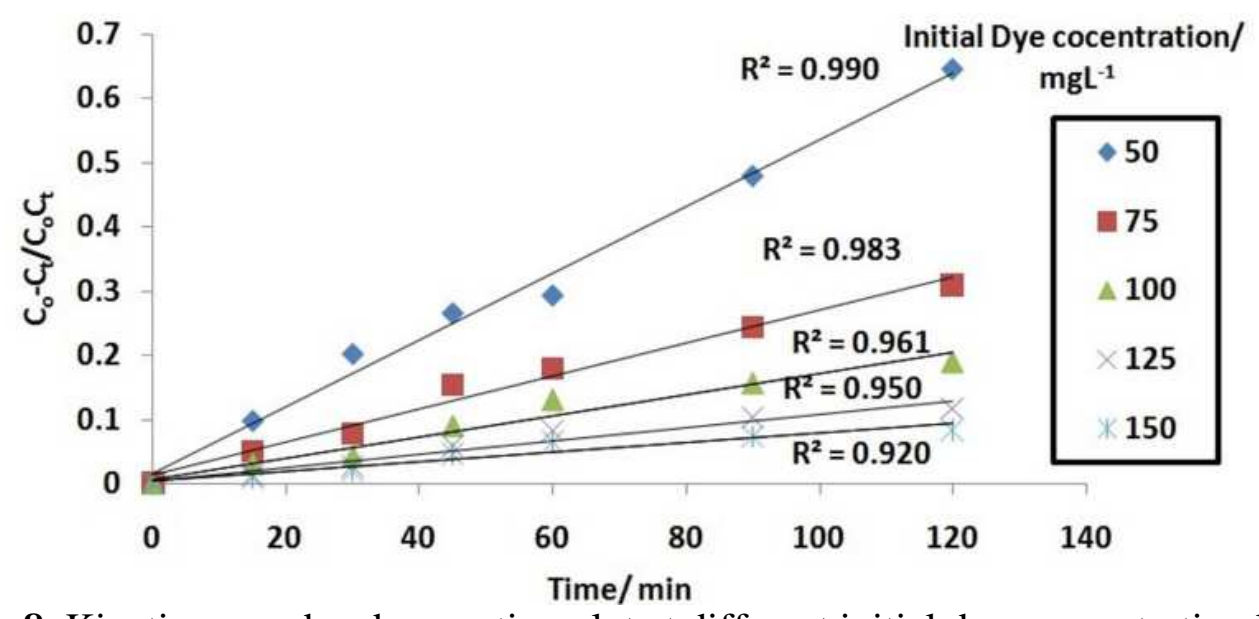

Figure 8. Kinetic second-order reaction plot at different initial dye concentration levels.

Table 1. Values of rate constant $\mathrm{K}_{2}$ for second-order kinetic rate equation at different initial dye concentration levels.

\begin{tabular}{cccccc}
\hline Initial dye concentration, $\mathbf{~ m L L}^{-1}$ & 50 & 75 & 100 & 125 & 150 \\
\hline Rate constant, min $^{-1}$ & 0.0051 & 0.0025 & 0.0016 & 0.0010 & 0.0007 \\
\hline
\end{tabular}

\section{Analysis of COD}

The chemical oxygen demand analysis allows the feasibility of waste in terms of the total quantity of oxygen required for the oxidation of organic matter to $\mathrm{CO}_{2}$ and $\mathrm{H}_{2} \mathrm{O}$. This study has been taken as an effective parameter to measure the efficiency of the electrochemical oxidation process for the treatment of hazardous Congo red dye from aqueous solution. The volumetric analytical method was applied for COD measurement. The electrochemical degradation of Congo red has been carried out at different experimental conditions. Table 2 shows that the COD reduction percentage increases with the increase in current density, amount of supporting electrolytes (potassium chloride) and $\mathrm{pH}$ of the dye solution. This may be because the electrogenerated chlorine/hypochlorite plays an important role in the electrocatalytic degradation process of the dye removal [23-24]. However, the reduction percentage in COD value decreases with an increase in initial dye concentration, because dye molecules tend to associate with large molecules of low diffusivity, which may lower the dye diffusion to the anode.

Table 2. Analysis of COD at different operating conditions for electrochemical degradation.

\begin{tabular}{|c|c|c|c|c|c|c|c|c|c|c|c|c|c|c|c|c|c|}
\hline & \multicolumn{4}{|c|}{$\begin{array}{c}\text { c.d, } \\
\mathrm{mA} \mathbf{c m}^{-2}\end{array}$} & \multicolumn{5}{|c|}{$\begin{array}{c}\text { KCl amount, } \\
\text { gL }^{-1}\end{array}$} & \multicolumn{3}{|c|}{ pH } & \multicolumn{5}{|c|}{$\begin{array}{l}\text { Initial dye concentration, } \\
\mathrm{mgL}^{-1}\end{array}$} \\
\hline & 0.602 & 1.203 & 1.805 & 2.406 & 1 & 3 & 5 & 7 & 9 & 3.86 & 5.86 & 7.86 & 50 & 75 & 100 & 125 & 150 \\
\hline $\begin{array}{l}\text { COD } \\
\text { reduction } \\
\%\end{array}$ & 66.67 & 76.67 & 80 & 85 & 56.67 & 70 & 80 & 83.33 & 86.67 & 73.33 & 75 & 80 & 85.71 & 82.76 & 80 & 77.42 & 75 \\
\hline
\end{tabular}

\section{Electric energy consumption}

In the electrochemical oxidation process for the removal of Congo red dye from aqueous solution, the major operating cost is associated with electric energy 
consumption values. The electric energy consumption during the electrochemical process has been calculated in terms of $\mathrm{KWh} \mathrm{Kg}^{-1}$ dye removed, using the following equation [22]:

$$
\text { Energy consumption }=\frac{\text { Vit } \times 10^{\mathrm{z}}}{60\left(c_{0}-c_{\mathrm{t}}\right) \times \text { trected volume }(L)}
$$

where $\mathrm{V}$ is the cell voltage $(\mathrm{V}), \mathrm{I}$ is the current $(\mathrm{A}), \mathrm{t}$ is the time of electrolysis (min), $\mathrm{C}_{\mathrm{o}}$ and $\mathrm{C}_{\mathrm{t}}$ are the initial dye concentration and concentration of dye at time $\mathrm{t}$ in solution $\left(\mathrm{mgL}^{-1}\right)$. The contents of Table 3 indicate that the energy consumption increases with increasing current density, and decreases with increasing $\mathrm{KCl}$ amount. The minimum electrical energy consumption was 3.0864 $\mathrm{KWh} \mathrm{Kg}^{-1}$ colour removed at a very low current density of $0.602 \mathrm{~mA} \mathrm{~cm}{ }^{-2}$, which may be attributed to the decreased hydrogen and oxygen evolution reaction. With this very small electrical energy consumption, an almost complete degradation of dyes has been achieved after 60 min of electrolysis. In India $\sim 6.43$ rupees are required to remove one kilogram of dye from wastewater during this process.

Table 3. Electric energy consumption values at various parameters during electrochemical process.

\begin{tabular}{|c|c|c|c|c|c|c|c|c|c|}
\hline & \multicolumn{4}{|c|}{ c.d, $\mathrm{mA} \mathrm{cm}^{-}$} & \multicolumn{5}{|c|}{$\mathrm{KCl}$ amount, $\mathrm{gL}^{-1}$} \\
\hline & 0.602 & 1.203 & 1.805 & 2.406 & 1 & 3 & 5 & 7 & 9 \\
\hline $\begin{array}{l}\text { Energy } \\
\text { consumption, } \\
\mathrm{kWh} \mathrm{kg}^{-1} \\
\text { dye removed }\end{array}$ & 3.0864 & 6.6667 & 11.3025 & 17.1674 & 20.3007 & 13.9535 & 11.3025 & 9.6463 & 7.9365 \\
\hline
\end{tabular}

\section{Fourier Transform Infrared Spectroscopy (FTIR) analysis}

The FTIR spectra of Congo red dye before and after electrolysis at optimum condition have been recorded in the region of 4000-400 $\mathrm{cm}^{-1}$. The FTIR spectrum of Congo red showed peaks in $1062 \mathrm{~cm}^{-1}$ for $\mathrm{S}=\mathrm{O}$ stretching vibrations of sulfonic acid, $1225 \mathrm{~cm}^{-1}$ for $\mathrm{C}-\mathrm{N}$ stretching vibrations, $1361 \mathrm{~cm}^{-1}$ for $\mathrm{C}-\mathrm{N}$ bending vibrations, $1446 \mathrm{~cm}^{-1}$ for aromatic $\mathrm{C}=\mathrm{C}$ stretching vibrations, $1585 \mathrm{~cm}^{-1}$ for $\mathrm{N}=\mathrm{N}$ stretching vibrations, $2925 \mathrm{~cm}^{-1}$ for $\mathrm{O}-\mathrm{H}$ stretching vibrations and 3465 $\mathrm{cm}^{-1}$ for $\mathrm{N}-\mathrm{H}$ stretching vibrations of aromatic primary amine (Fig. 9(a)). The FTIR spectrum obtained after electrolysis of Congo red consists of no peak at $1585 \mathrm{~cm}^{-1}$, due to azo group [25]. The other peaks (visible in the spectra before electrolysis) weaken or disappear, as shown in the FTIR spectrum (Fig. 9(b)).

\section{Electrochemical degradation pathways of Congo red}

The intermediate compounds formed during the electrochemical degradation of Congo red have been identified by MS/MS. The sample has been collected after 60 minutes of electrolysis. Based on the MS/MS identification, the following pathway (Fig. 10) is proposed for the electrochemical degradation of Congo red. The structures of various intermediates, as predicted from MS/MS fragmentation analysis, are given below in Fig 10, with a base peak at 113, indicating that the entire dye has been decomposed to low molecular weight fragments. 

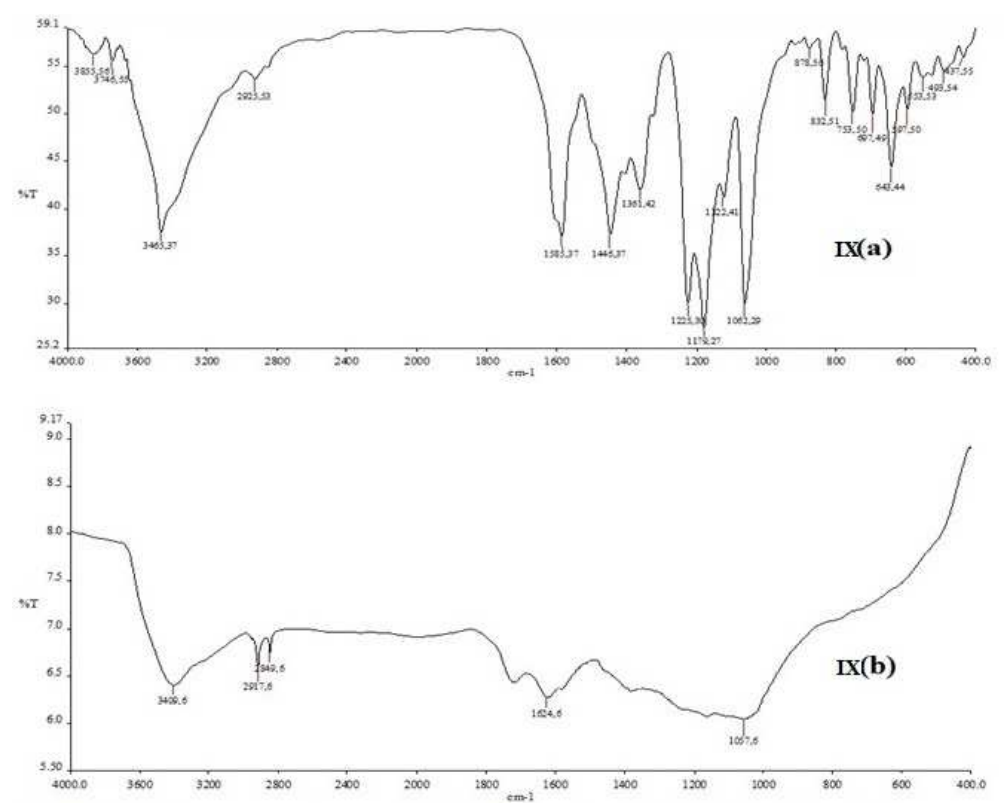

Figure 9. FTIR spectrum of Congo red dye IX(a) before electrolysis, IX(b) after electrolysis.

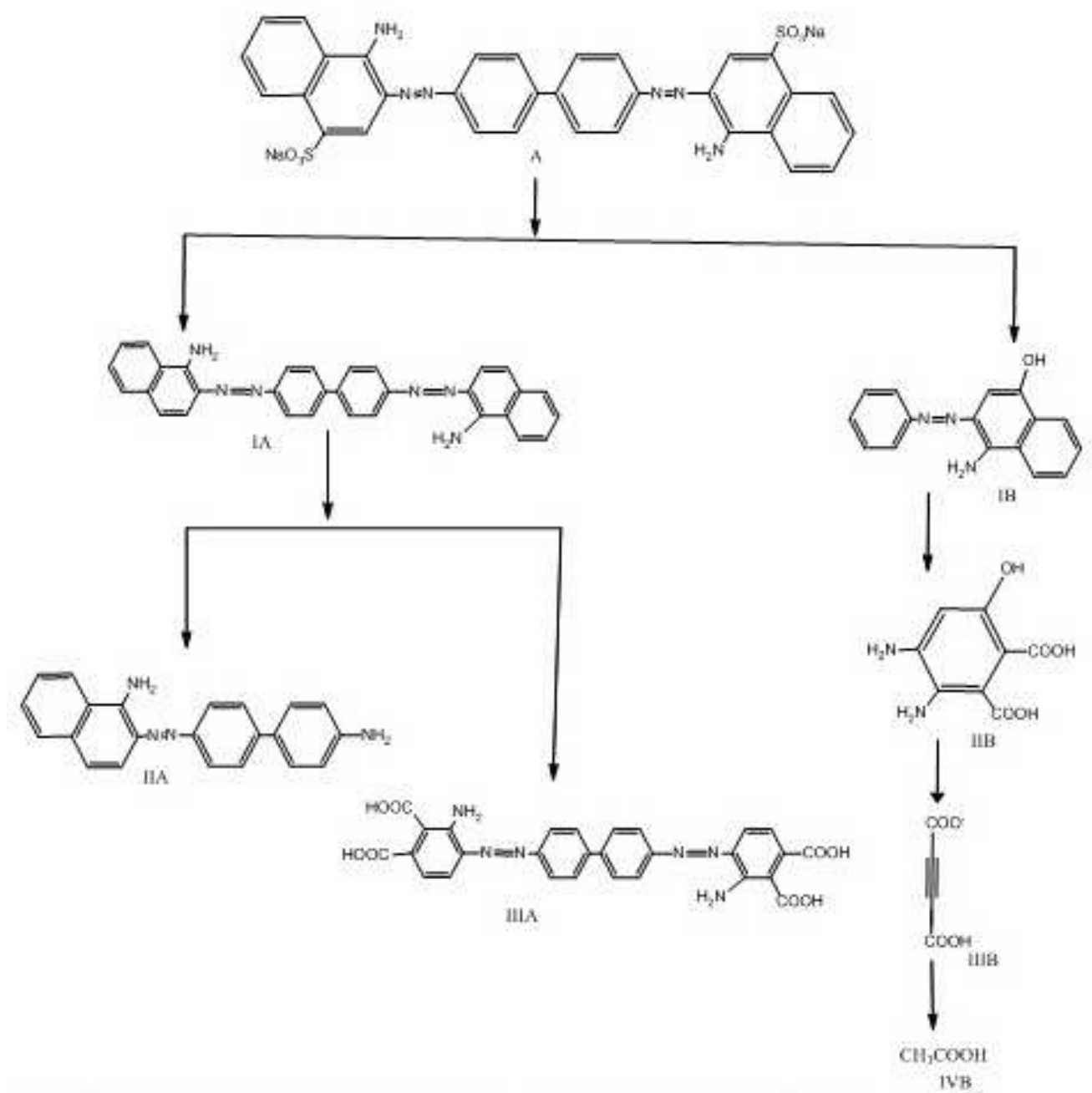

Figure 10. Proposed pathways of electrochemical degradation of Congo red. 


\section{Conclusions}

The present work is devoted to the electrochemical oxidation of textile dye Congo red at graphite anode and platinum cathode under optimum conditions. This process is capable of destroying the harmful dye contents in short treatment time. The influence of current density, initial dye concentration, $\mathrm{KCl}$ concentration, $\mathrm{pH}$ and electrode material on the dye removal percentage and COD reduction has been determined. The intermediates formed during electrolysis have been identified with MS/MS and FTIR spectral studies. It is interesting to notice that $95 \%$ of dye has been degraded during electrolysis with maximum energy resource management. The present data were well fitted to second-order kinetic model for the electrochemical process. Thus, electrochemical technology is an effective method for the removal of Congo red dye from effluents of textile industry.

\section{Acknowledgements}

Authors acknowledge sincere thanks to UGC, New Delhi, for awarding the UGC-BSR Fellowship (to Ms. Rajvir Kaur) for carrying out the research work successfully.

\section{References}

1. Ramakrishna KR, Viraraghavan T. Water Sci Technol. 1997;36:189.

2. Baban A, Yediler A, Ciliz NK. Clean - Soil Air Water. 2010;38:84.

3. Robinson T, McMullan G, Marchant R, et al. Bioresource Technol. 2001;77:247.

4. Ho YS, Mckay G. Can J Chem Eng. 1998;76:822.

5. Walker GM, Hansen L, Hanna JA, et al. Water Res. 2003;37:2081.

6. Jain R, Sharma N, Radhapyari K. Eur Water. 2009;27/28:43.

7. Weber WJ, Morris CJ. Advances in water pollution research. In: Proceedings of the First International Conference on Water Pollution Research. vol 2. Oxford: Pergamon Press; 1962. p. 231.

8. Kaur H, Swati, Kaur R. Chem Sci Trans. 2014;3:1300.

9. Han R, Ding D, Xu Y, et al. Bioresour Tech. 2008;99:2938.

10. Yang CL, McGarrahan J. J Hazard Mater. 2005; 127:40.

11. Saleem M, Bhkhari AA, Akram MN. J Basic Appl Sci. 2011;7:11.

12. Katwal R, Kaur H, Sharma G, et al. J Ind Eng Chem. 2015;31:173.

13. Lopes A, Martins S, Morão A, et al. Port Electrochim Acta. 2004;22:279.

14. Kaur H, Kaur R. J Mater Environ Sci. 2014;5:1830.

15. Forgacs E, Cserhati T, Oros G. Environ Int. 2004;30:953.

16. Nava JL, Quiroz MA, Marinez-Huitle CA. J Mex Chem Soc. 2008;52:249.

17. Jović M, Stanković D, Manojlović D, et al. Int J Electrochem Sci. 2013;8:168.

18. Rivera M, Pazos M, Sanromán MA. Desalination. 2011;274:39.

19. El-Ashtoukhy ESZ, Amin NK. J Hazard Mater. 2010;179:113.

20. Clesceri LS, Greenberg AE, Trussell RR, editors. Standard methods for the examination of water and wastewater. 17th ed. 1989. 
21. Wang CT, Chou WL, Kuo YM, et al. J Hazard Mater. 2009;169:16.

22. El-Ashtoukhy ESZ. Int J Electrochem Sci. 2013;8:846.

23. Kariyajjanavar P, Narayana J, Nayaka YA, et al. Port Electrochim Acta. 2010;28:265.

24. Ghalwa NMA, Abdel-Latif MS. J Iran Chem Soc. 2005;2:238.

25. Telke AA, Joshi SM, Jadhav SU, et al. Biodegradation. 2010;21:283. 